\title{
"The evaluation of the heritage of the 1956 South African water policy"
}

\begin{tabular}{|c|c|c|}
\hline AUTHORS & Bulewa Maphela & \\
\hline ARTICLE INFO & $\begin{array}{l}\text { Bulewa Maphela (2016). The ev } \\
\text { water policy. Environmental Eco } \\
\text { 1).2016.03 }\end{array}$ & $\begin{array}{l}\text { itage of the } 1956 \text { South African } \\
\text { 3-119. doi:10.21511/ee.07(4- }\end{array}$ \\
\hline DOI & http://dx.doi.org/10.21511/ee.07( & \\
\hline RELEASED ON & Wednesday, 21 December 2016 & \\
\hline JOURNAL & "Environmental Economics" & \\
\hline FOUNDER & LLC "Consulting Publishing Con & Perspectives" \\
\hline & & 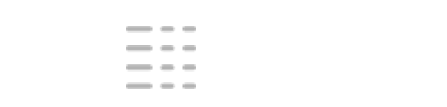 \\
\hline NUMBER OF REFERENCES & NUMBER OF FIGURES & NUMBER OF TABLES \\
\hline 0 & 0 & 0 \\
\hline
\end{tabular}

(c) The author(s) 2022. This publication is an open access article. 


\title{
Bulewa Maphela (South Africa)
}

\section{The evaluation of the heritage of the 1956 South African water policy}

\begin{abstract}
Purpose: Water management issues in poor communities in South Africa were never addressed directly by apartheid policies. The 1956 water policy was found not to be holistic in the management of the resource within the country. The growing economy of South Africa resulted in explosive urbanization, which gave rise to an increasing number of townships. The purpose of the paper is, therefore, threefold, namely: it outlines the water management challenges resulting from the 1956 water policy, it outlines the progression of implementing the apartheid ideologies in water management and, lastly, it relates the old policy of water management to today's environment. The 1956 water policy had a colonial perspective, thus, this has created an observable challenge in the current endeavors of the water management regime. These challenges are presented in the paper in an effort to illustrate that the failures of today's policies are largely historically embedded.

Design/methodology/approach: A comprehensive framework of the evolution of the water management regime from the DWA's library was used. Databases that contained historical policies of South Africa were also used to do a rigorous literature review. Because of the nature of the research, the study, therefore, uses both qualitative and quantitative methods of investigation.

Findings: The old apartheid policies created a challenging ideological environment in the townships. This has resulted in the difficulty of implementing the current water policy in water management. The unintended consequences are difficult to factor into the current policies. Over time, communities collaborated and became defiant. The defiance of the water policy by the communities resulted in non-payment for the use of the resource.

Implications: The challenges surfacing in the paper seem to imply that the current policy implementation in water management has an observable challenge that has a potential of hindering policy discourse in water management.

Originality/value: New democracies have a tendency of being overly ambitious about the inclusive nature of the policy discourse. Ideologically, this means that implementation of the new policies cannot be done without challenges. This paper attempts to highlight that the 1956 water policy systematically created certain social norms and ideologies that have the potential to hinder new policy ideals in the townships.
\end{abstract}

Keywords: water policy, black townships, apartheid ideologies, social dilemmas and water management practices. JEL Classification: Q25, J71.

\section{Introduction}

Hirschl (2001) refers to political reform as judicial empowerment through the constitutionalization of rights as an outcome of political efforts by an organized group with a view to abolishing the malpractices of the regime in office. This reform in South Africa has given political rights to previously disadvantaged citizens. South Africans of all races are now able to vote, which means that they have a say in the political transformation of their country. In any political reform, many issues have to be dealt with, in South Africa, on top of all the agendas for policy reform, was the water policy of the apartheid regime which was largely discriminatory against certain races. South Africa followed the guidelines of the 1956 water policy until the post-apartheid democratic government came to power in 1994.
This article summarizes and expands the findings and conclusions of a research project undertaken to assess the consequences and legacy of the 1956 water policy of South Africa from the perspective of poor black communities (Maphela \& Cleote, 2015) ${ }^{6}$.

\section{Research design and methodology}

The methodology takes the view that personal stories will be woven into the statistics of water usage and patterns thereof. Because of the nature of the research, the study, therefore, uses both qualitative and quantitative methods of investigation. Babbie and Mouton (2005, p. 3), in support of the qualitative paradigm, suggested that the primary goal of a qualitative study lies in its focus on understanding the people studied in terms of their social environment and their perception of the content. A discussion of the main views on the topic by different disciplinary experts in the water

\footnotetext{
${ }^{6}$ Unpublished doctoral thesis in the Department of Public Management and Governance at the University of Johannesburg by the first author under the supervision of the second author (Maphela, 2015).
} 
field will be undertaken to provide the best practices context for assessing the effectiveness and efficiency of the current South African policy approach. The assessment of the academic literature on the topic will be supplemented by the examination of policy literature and practices.

\section{Brief overview of the 1956 water policy}

According to Schreiner \& Hassan (2011), water appropriation challenges in South Africa date back to the entrance of the European colonizers in 1652. This resulted into a divide and rule approach by the colonizers whereby colonial powers displaced Africans, which meant that their ownership of resources was restricted or stripped. The British mining houses and banks hinged with the patriarchal elite alliance and formed the Union of South Africa in 1910 (Sauls \& Bond, 2014). This new colony legalized these activities, which included that blacks were denied a vote and the use of military and police to enforce the expropriation of blackcontrolled land. Pirie (1983) further states that after the accession of power by National Party in 1948, the Group Areas Act was passed to enable the control of the movement of blacks through divided ethnical settlements. Seeking (2010) also found that the Group areas Act of 1950 enabled forceful removal of blacks in the cities to the outskirts of town, where control was further enabled. These developments paved the ground for further policies to support the ideals of the previous regime, such as the 1956 water policy. The 1956 water policy was, according to Pienaar \& van der Schyff (2007), based on a combination of Roman-Dutch and English legal principles. This meant that water was controlled through a riparian system, which, in turn, required that access to water was part and parcel of the ownership of land Kapfudzaruwa \& Sowman (2009).

The riparian right was brought into full practice in 1873 by Sir Henry de Villiers, then, the Chief Justice of the Cape Colony. This riparian right meant that the owners of land were given spontaneous access to water that flowed from bordering land (Tewari, 2009). The author also acknowledged that there was an important rule within the riparian right; the owner of this riparian right had a right to use water from the public stream provided that the resource was used in a reasonable manner. This was the first element of ambiguity within the systems that fell under this policy. Pienaar (2009) concurs with Tewari (2009) that the water affairs in place during that time had an element of ambiguity by stating that the true official position of water had also been rather imprecise and could not exactly be defined. The riparian right principle indicates that the government played a trivial role in the allocation of water rights and the development of water resources. Various authors such as Tewari (2009) \& Pienaar (2009) identified many shortcomings of this riparian principle, including the fact that it did not give the owner of the land ownership of the resource.

\section{The implementation of the 1956 water policy}

The Constitution of South Africa came into effect in 1910 through the association of four sovereign areas which became part of the British Commonwealth (Thompson, Sfimie, Richters \& Perret, 2001). The four unified independent areas were the Zuid-Afrikaansche Republic (Transvaal), the Republic of the Orange Free State, Natal and the Cape Colony. This unification ended in 1961, when South Africa separated from the Commonwealth and became the Republic of South Africa. This, consequently, gave rise to the creation of the highest legislative structure, namely the Parliament, of which representatives were elected by the white minority group in 1956. In 1961, the Parliament was already an institution with the topmost legislative powers which included unlimited lawmaking. These new-found powers ran concurrently with the Group Areas Act. This Act resulted in separate institutions for each racial and ethnic group. According to the History of South African Segregation (1910-48) the Native Land Act (No27) of 1913 effected the separation of South Africa into areas whereby whites could own freehold land while blacks had no right to own land at all. The white population who constituted about one-fifth of the population were given $92.5 \%$ of the land, whilst blacks and other races who constituted two thirds of the population were restricted to $7.5 \%$ of the land. According to Scheiner \& Hassan (2011), colonial powers displaced Africans by stripping them of ownership of land and water resources. This meant that blacks could live on their land only if employed as labor by white employers. Upon employment, black laborers were viewed as temporary dwellers in the cities and were forced to periodically return to the rural areas to meet the labor needs of the farming population. Therefore, this Act also served as a support to mining companies and a control measure for migrant labor absorbed by the mining industry. In the content of this Act, there was further division which resulted in South Africa having various independent and autonomous states, which did not have political control over the matters of the South African political environment. These states came to be known as homelands or Bantustans The homelands were separated according to ethnic groups. Scheiner \& Hassan (2011) also found that after the apartheid government came into power in 1948, the native reserves were merged into nine socalled homelands through a wave of forceful ejections. 
This was seen as a control strategy to avoid collaboration and rioting. These homelands were on the outskirts of the major urban areas. Reed (2005) states that this division of ethnic groups by boundaries allowed Africans to own or lease land. These pieces of land were known as native reserves, which also meant that no person from these reserves could own land outside the designated native reserves. Reed (2005) discovered that the Group Areas Act of 1950 was also a strategy orchestrated to alter the labor market to supply white enterprises, particularly mining and farming.

Therefore, the role of the state, according to Duncan (1990), was to create conditions in which mining, farming and industrial capital formation could thrive. The state also took steps to provide employers with differentiated labour with an Aid of the native labor organization, which automatically had classifications of labor. Duncan (1990) supports this by stating that the commissioner of safety during this time advised that the best way to make millions in mining was to remove white miners who worked underground and replace them with unskilled labor extracted from the homelands, which was in over-supply. The territorial segregation also resulted in the displaced race losing rights to water. This was sealed by the Irrigation and Conservation of Water Act of 1912, which entrenched the lawful appropriation of most of South Africa's resources by whites. Tewari (2009) noted that the development of water laws in South Africa was historically woven within a fabric of both economic and political colours. These colours were specifically for the purpose of conquest and colonization.

The 1956 water policy evolved from the changing of the water policy from the Dutch to the British, and, then, to the Afrikaners, which were the National Party and the rulers during the tenure of this water policy (Tewari, 2009). However, the main stratagem of the policy was that it was adopted from the British common-law riparian rights system. In the debates by various authors such as Tewari \& Pienaar, this system was most appropriate as riparian landownership had already sprung up with exclusive water rights to whites only.

The water policy of 1956 of the Department of Irrigation resulted in the establishment of the Department of Water Affairs (DWA). This department was primarily mandated with a task of affording and allocating water development in the agricultural sector, mining and suburban areas. Many authors highlighted the fact that the policy was silent on matters relating to township users. During the tenure of this policy, black people had limited basic rights, a situation that was legalized by the promulgation of several discriminatory policies (Funke, Nortje, Findlander, Burns, Turtons, Weaver \& Hattingh, 2007). Therefore, this was regarded as an effective weapon in the apartheid government's arsenal of oppression and control.

Since the world is not static, neither is the environment. Under this policy, the demand management of water was not narrated, only the supply side could be traced. Droughts were forecast and were evident around the 1980s. In the early 1990s, the government was prompted to consider the implementation of emergency water schemes. In the process of seeking emergency water schemes and the building of new dams, scientists such as Turton (2002) warned that this was not an ideal solution, as the climate was changing (van der Merwe, 2009, Sept 11 Engineering News). According to this scientist, other ways should have been considered instead of focusing on the supply side of water only. During the 1980s, it became evident that the unsustainable way in which South Africa's water resource had been managed resulted in worrying levels of degradation of many primary water services. In addition to this, it has been stated extensively that South Africa is a semi-arid region. The climatic changes experienced world-wide prompted South Africa to consider its water affairs. This coincided with the taking over of the government by the African National Congress (ANC).

\section{1956 water policy, panacea or originator of challenges in water management}

Funke, Nortje, Findlater, Burns, Turton, Weaver \& Hattingh (2007) narrated that the water policy of 1956 gave effect to the Department of Water Affairs (DWA). The major tasks of this department were to provide and allocate water for developing the agricultural sector, where the Nationalists' Party regime had a strong support base. Funke et al. (2007) further state that black people had very few basic rights during the tenure of the 1956 water policy. Their access to running water and sanitation was also affected. The created homelands had to bargain to obtain water rights and licenses in rivalry with other users outside of their territories. Water, thus, became a very effective weapon for the nationalist government (Amisi \& Nojiyeza, 2008). This weapon of separating ethnic groups and taking away the rights of ownership and political powers was part of the management of the scarce resource. This resulted in water management being a delicate exercise, exacerbated by the fact that the climate had been gradually changing, altering the availability of fresh water (Turton, 2002). The economy was also growing at an alarming rate; 
urbanization took place, because mining activities were also growing (Turok, 2012). This meant that the people within the native reserves left the homelands to look for jobs in the mining sector (Bonner, 2009).

\section{Challenges of the 1956 water policy for South Africa}

Prior to the social, economic and other documented challenges that the 1956 water policy was faced with, it is important to examine its theoretical challenges. One of the greatest challenges of the policy lied in the lack of governance. Pienaar \& van der Schyff (2007) also concurred that water resource reform was a crucial element in addressing the inequalities of the past regime, where governance lacked at all levels of all existing policies. Pavlov (2006) briefly defined governance as an absence of coercive state power. Since, within this water policy, the main agenda for government was to use the resource as a political tool, the black communities in the Bantu stands or homelands were never part of the management of the resource, as it belonged to the state under the apartheid government. Donkor (2006) stated that during the early 1950s in Africa, the population was doubling, but the use of water was tripling. Countries were approaching the mark of reduced physical fresh water. In countries like South Africa, urban settlement was expanding due to the increasing economic activities, such as mining, followed by agricultural activities and industrial activities. The population from the homelands moved to the cities and it was largely unskilled people seeking employment (Bonner, 2009). In South Africa, the housing settlement issues exacerbated the problem. The amount of water that was regarded as sufficient for one household was no longer adequate because of the movement from rural areas to cities. Alexandra Township is a typical example of this scenario. The World Bank: Project Spotlight (2001) states that Alexandra Township (Alex) was founded in 1912. Alex covers an area of over 800ha and its infrastructure was planned for a population of about 70000 . Currently the population estimates are ranging from 180000 to 750000 . The original stand size is 500-600 sq.m, which is characterized by a household with additional separate rooms built in the gardens, with tenants renting from the original stand owner. This unforeseen population explosion congested the infrastructure, such that water pressure was low and sewers frequently blocked and overflowed (Wold Bank, Project Spotlight, 2001).

\section{Types of migration in and around 1956}

Bonner (1995) differentiated between two types of migration, namely, first generation migrants and second generation migrants to the city of Johannesburg from the homelands. During the 1930s and the 1950s, the African population from the rural reserves or homelands was overwhelmingly first-hand migration which meant that they were moving from first to second status. The study assumes that the first-hand status was that of being a black African based in the homelands, whereas the second status was that which was acquired by migrant labor status. The need for migrant labor was becoming important to fill the gaps in the growing economy. The colonial drive was still lingering in the shift of policy content, which was open to migrant settlement in urban areas. Cook (1986) stated that the colonial drive persisted towards the segregation of races in the new shift in policy content. In recognizing the importance of black labor, some employers provided accommodation for laborers on their premises. Cook (1986) also discovered that from 1901, the hostels started to emerge. This type of dwelling was meant for single male migrants, which immediately became a family accommodation unit, which accommodated a ratio of single to 1.5 families per unit. This manner of settlement was also another weapon to control family expansion, as the men would go home to the homelands and expand their families in that confinement instead of in the urban areas. Around the 1960s, signs of in-migration were on the rise. Cook (1986) narrated that in 1960 in the Cape Town area there were about 60000 black residents. By 1970, the number of in-migration rose to 92572 , at the end of 1970 it was 180 400. This was not only happening in Cape Town, Johannesburg was also experiencing its share of rising levels of in-migration because of the mining industry. Wisner (1995) found that other groups of migrants from rural areas also contributed in setting up illegal shacks on the land next to places of employment. This gave rise to squatters; the families were kept there, while the men resided in the hostels.

This type of dwelling was becoming uncontrollable and the hostile environment which posed health hazards and put pressure on the government to consider a revisit of the policy content of controlling blacks in urban areas. Duncan (1990) stated that the health hazards were already obvious from 19181948, as the Public Health Department officers cautioned about the conditions in the compounds that were very unhygienic. This meant that when the migrant labor pool was off duty, it endured the hazards of slum conditions, and, then, had to walk miles to work each day.

It was during this time that the government decided to build cost effective houses outside the cities to accommodate the growing black population. The settlement into these houses was in such a way that 
the aspirations of segregation were still maintained, as the ethnic groups were separated again with a hope of preventing collaborations amongst them. This type of dwelling was close together hindering the natural drainage lines and preventing the conservation of trees (Wisner, 1995). The infrastructure that was provided was basic and the subdivision of locations placed a burden on the provided facilities of water drainage and sanitation. The policy proved to be a failure, as there were defiance campaigns against the regime, which was evident in 1976 during the June school uprising, by students from all ethnic groups. Again, in the mid1980s, the township uprising also manifested in the form of defiance campaigns (Simon, 1988). These defiance campaigns were meant to boycott the paying of rent for the houses and other services, such as water provision and sanitation. This was evidenced in the financial records of the struggling municipalities whose revenues were dwindling at a fast rate. In 2011, the Mail and Guardian, Dlamini (2011) stated that the non-payment of services were still the biggest challenge of most of the townships in South Africa. The author Dlamini (2011) further found that, whilst Gauteng was regarded as the richest province, it continued to struggle with the collection of municipal revenues, due to non-payment of services such as water, electricity and waste removal. Infusing this to the historical challenges of the policy under review, it can be deduced that the current challenges were inherited from the past policies, such as the one under review (Fjelstad, 2004). The current amounts owed by the municipalities can be attributed to the legacy of the culture of non-payment of services. Sidimba (2015) warned that the municipal debt was growing on a monthly basis. The author found that by the end of June in 2014, the consumer municipal debt in Gauteng amounted to R94 billion. This huge debt was inherited from the culture of non-payment that was part of fighting against the unjust policies.

\section{The social impact of the 1956 water policy}

The apartheid government was under a considerable amount of pressure from the international community. As a result, South Africa has put under sanctions for its apartheid policies that undermined the black communities. Wisner (1995) concurred that resistance to the apartheid regime resulted in the 1980s campaigns of un-governability. Political organizers urged communities to refuse to pay for utilities and rent, because the government, at that time, was seen as non-representative and service provision was poor.

Communities also took heed of the call to oppose these policies by engaging in defiance campaigns that involved non-payment of major basic services.
Cook (1986) stated that for the government to finance the black townships, it had to raise money from the white electorate and state resources. The riots and boycotts in the black municipal townships were fast becoming a burden that needed attention.

Weyrauch \& Diaz Langou (2011) suggested that acquiring knowledge about the impact of certain policy processes has the advantage of providing to policy practitioners reasons why interventions could achieve desired results. Previously, in developing countries, policies were largely opinion-based, a good example being that of South Africa where many policies served the needs of the preferred race. This resulted in poor policy design and inefficient development outcomes. In an attempt to contextualize the analysis, it is vital to state the possible causes of breakdowns within the policy orientation content. Since the water policy lacked governance, it follows that its implementation was of a traditional opinion-based policy practice nature. Politics played an important role in the design of this policy. One of the major characteristics of the South African way of government was the marginalization of certain races, which was a sign of non-governance. South Africa has been environmentally defined as a semi-arid region, which signals that there was a conflict between the environment and the social order. Pienaar \& van der Schyff (2007) state that prior to 1998, the real legal status of water had always been ambiguous with no clear definitions. Water was used as a mechanism to discourage the movement of migrants into the cities.

Ethnic groups were successfully separated to achieve the objectives of non-collaboration of communities and, as a political tool, the objectives of the policy were met. The body of knowledge on policy process has always hinted that policies have a tendency of producing unintended consequences. The water policy of 1956 illustrated what could have been inherited by the 1998 water policy: the unintended consequences. In the South African situation, due to the policy change process that was a result of a political transition, there was not enough time to conduct extensive impact evaluation of the previous policy in water management. Therefore, the 1998 water policy was based on the international guidelines and the restorative judicial system. The evidence of the previous policy was that of marginalized communities. The attitudes of these communities were not part of the policy agenda.

Hence, Segone (2010) advised on evidence based policy, which he defines as a methodology which supports people make well knowledgeable decisions about policies, programs and projects by putting the best available substantiation at the heart of policy 
development and implementation. It is envisaged that evidence based policy making refers to a type of policy process that aids planners with better informed decisions by putting the best available evidence at the centre of the policy process. This pillar is missing in the 1956 water policy. It is one of the gaps that were supposed to have been addressed in the 1998 water policy. This is supported by the results of the surveys in the selected communities. The results indicate that there was no meeting of the minds between the communities and the policy agenda.

\section{Transition to the 1998 water policy}

Compared to the 1956 water policy, the 1998 water policy endeavored to put corrective measures on socio-economic rights, of which the water policy needed immediate attention. Francis (2005) noted that policy restructuring was a principal focus during the period of conversion, as apartheid policies left a legacy of inequality, even in the provision of basic services such as access to water. The new Bill of Rights (No.108 of 1996) puts it correctly that the provision of these services was seen world-wide as a precondition to improving standards of living amongst the millions of poverty burdened citizens. Mathipa \& Roux (2009) stated that the constitutional provision required that the state should take reasonable legislative and other measures within its available resources to strive for advancing realization of human rights. The major water policy change is reflected in the national government activities through the Minister of Water Affairs and Forestry as the public trustee of the nations' water resources. The responsibility rested on previous Minister Kader Asmal to drive the water policy shift from the 1956 content to the more progressive water policy of 1998. This new government immediately tackled the environmental issues and the provision of basic needs for the majority who were previously side-lined. This resulted in the scrapping of the 1956 water policy and the drafting of the new guidelines for the water policy of 1998 (Mathipa \& Roux, 2009). The election of the new government in SA in 1994 called for a change in priorities, philosophies and a new approach to management of water resources and its allocation.

\section{Conclusion}

South Africa has always been a semi-arid region. The apartheid laws of the country were mainly formulated to uphold the apartheid ideologies. Consequently, the 1956 water policy leaned on control rather than mitigating the challenges of the aridity of the country and the usage patterns of water resources. In strengthening the apartheid laws, it was found that race and ethnic groups were separated to create a conducive environment for apartheid discourse. The paper has evidenced that for each and every policy, there are unintended consequences in the long run. In the country's water regime, the consequences of the apartheid laws manifested in the townships. Overtime communities collaborated and became defiant. The defiance of the water policy by the communities resulted in nonpayment for the use of the resource. In the analysis of the 1956 water policy, it, therefore, surfaced that the social impact of the policy needed attention for any water management practices to succeed.

\section{References}

1. Amisi, B. \& Nojiyeza, S. (2008). Access to Decent Sanitation in South Africa: The Challenges of Eradicating the Bucket System. AfriSam Conference. Durban. February 2008.

2. Bonner, P. (1995) African Urbanisation on the Rand between the 1930s and 1960s: its Social character rand Political consequences, Journal for African studies. South Africa. Taylor \& Francis Group, 21(1), p. 115.

3. Bonner, P. (2009). Labor, Migrancy \& Urbanisation in South Africa \& India 1900-60, Journal of Asian \& African Studies, 44(1), pp. 69-95.

4. Cook, G.P. (1986). Khayelitsha: Policy, Change or Crisis Response? Institute of British Geographers, New Series, 11(1), pp. 57-66.

5. Dlamini, A. (2011). Non-Payment Hits Revenue Collection in Gauteng. Mail \& Gaurdian (11 May 2011).

6. Donkor, S.M. (2006). Water in Africa: Management Options to Enhance Survival and Growth. Economic Commission for Africa. September 2006. NEPAD Support Unit.

7. Duncan, D. (1990). Structure and Experience in the Making of Apartheid, 6-10 February 1990, pp. 1918-1948. African Library Wits University.

8. Fjeldastad, O. (2004). What's Trust Got to Do With it? Non-payment of Services Charges in Local Authorities in South Africa, Journal of Modern African Studies, Cambridge University Press. London.

9. Francis, R. (2005). Water Justice in SA: Natural resources Policy at the Intersection of Human Rights, Economics \& Political Power. The Berkeley Electronic Press (bepress). Paper 518.

10. Funke, N., Nortje, K., Finlater, K., Burns, M., Turton, A., Weaver, A. \& Hattingh, M. (2007). Science and Policy for Sustainable Development, Journal: Environmental, 49(3), pp. 10-23.

11. Hirschl, R. (2000/1). The Origins of judicial Empowerment through Constitutionalisation: Lessons from Four Constitutional Revolutions. Law \& Social Enquiry. 
12. Kapfudzaruwa, F. \& Sowman, M. (2009). Is There a Role for traditional Governance System in South Africa's new Water management Regime, Water SA, October 2009, 35(5).

13. Maphela, B. (2015). Critical Assessment of the South African Water Policy. Thesis. University of Johannesburg. Aucklandpark.

14. Mathipa, K.S. \& le Roux, C.S. (2009). Determining water management training needs through stakeholder consultation: Building users' capacity to manage their water demand, SA, Water SA, 35(3), p. 253. ISSN: 03784738 .

15. Pavlov, P. (2006). The State Governance \& Administration in European Context, Varna Free University.

16. Pienaar, S.J. \& van der Schyff, E. (2008). The reform of Water Rights in South Africa. Legal Aspects of Water Sector reform. Geneva. Swiss International Foundation.

17. Pirie, G.H. (1983). Urban Population Removals in South Africa, Geography, 68(4).

18. Reed, D. \& de Wit, M. (2003). Towards a Just South Africa: The Political Economy of natural Resources Wealth. DWA. CSIR. Pretoria.

19. Richter, B.D. et al. (2003). Ecological Sustainable Water Management: Managing River Flows for Ecological Integrity, Ecological Application, 13(1), pp. 206-224. Ecological Society of America.

20. Sauls, J.S. \& Bond, P. (2014). South Africa: The Present as the History: From Mrs Ples to Mandela \& Marikana. Jacaranda Media (Pty) Ltd, Pretoria.

21. Schreiner, B. \& Hassan, R. (2011). Transforming Water Management in South Africa: Designing and Implementing New Policy Framework. Springer.

22. Seeking, J. (2010). Race, Class \& Inequality in the South African City. CSSR Working Paper No. 283. November 2010 .

23. Segone, M. (2010). Country -led Monitoring and Evaluation Systems. Better Evidence, Better Policies, better Development results. Unicef Evaluation Office. Three United Plaza. New York.

24. Simon, D. (1998). Crisis \& Change in South Africa: Implications for the Apartheid City, Vol. 14, pp. 189-206. Britain.

25. Tewari, D.D. (2009). A Detailed Analysis of The Evolution of Water Rights in South Africa. An Account of Three and a Half Centuries from 1652 AD to Present. Water SA, Oct 2009, 35(5), pp. 693-710.

26. Thompson et al. (2001). Policies, legislation and Organizations related to Water in SA, with special reference to the Olifants River Basin. Working Paper 18 (SA Working Paper No.7): Colombo, Sri Lanka: International Water Management Institute.

27. Turok, I. (2012). Urbanisation \& Development in South Africa: Economic Imperfections, Urbanisation \& Emerging Population Issues. Working Paper 8. International Institute for Environmental \& Development. London.

28. Van der Merwe, C. (2009). Turton Urges SA to Intergrade, Water Energy an Agricultural Policies. Available at: http://www.engineeringnews.co.za/article/turton-urges-sa-to-integrate-water-energy-and-agricultural-policies2009-09-11.

29. Weyrauch, V. \& Diaz-Langou, G. (2011). Sound Expectations: From Impact Evaluations to Policy Change. CIPPEC. Working paper Series Production Team: International Initiative for Impact Evaluation. New Delhi. Available at: www.3ieimpact.org.

30. Wisner, B. (1995). The Reconstruction of Environmental Rights in Urban South Africa, Human Ecology, 23(2), pp. 259-284.

31. World Bank Development Indicators. (2010). Reconstruction \& Development. The World Bank. Washington DC. 20433 USA. 